\title{
対馬における「コヤ(板倉)」の THE CHARACTER OF THE WOODEN 建築構法の特性 \\ CONSTRUCTION SYSTEMS OF STOREHOUSES "KOYA" IN TSUSHIMA IS. NAGASAKI
}

$\begin{array}{ll}\text { 小林久高— } * 1 & \text { 安藤邦廣——2 } \\ \text { 黒坂貴裕— } * 3 & \text { 濱 定史— } \\ \text { 柳 和 先— } * 1 & \text { 釜床美也子 }-* 1\end{array}$

キーワード :

対馬, 倉, 木造構法，コヤ、ヒラバシラ

Keywords :

Tsushima, Storehouse, Wooden construction system, Koya, Hirabashira
Hisataka KOBAYASHI- $* 1$
Takahiro KUROSAKA- $* 3$
Hwasun YOU

Kunihiro ANDO $* 2$

Sadashi HAMA- $* 1$

Miyako KAMATOKO — $* 1$
In Tsushima Island, characteristic wooden storehouses are distributed. They are constructed with large stony roof and pillars have rectangle section.

The distribution and the structure of storehouses are investigated on this report. As a conclusion it is realized that the construction system of storehouse of Tsushima has high originality against other part of Japan, and on the detail of structure present some difference depending on size of stony roof.

\section{1.はじめに}

長崎県対馬市には「コヤ」光と呼ばれる板倉が数多く分布している。 長方形断面のヒラバシラを用い、屋根は板石で草かれるなど特徴的 な構法の見られる建築物であるが既往の研究は少ない。建築構法に

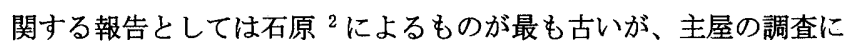
伴う概略的なもので、コヤの建築構法の特性を記述するには至って いない。近年の浅川 ${ }^{3}$ による報告は事例数が 2 例と少なく、構法の 詳細については触れられていない。その他には民俗学の分野からの 矢野 ${ }^{4}$ の貴重な報告があり、多くの聞き取りに基づいたコヤに関す る記述が見られるが、構法に関する記録は不十分である。集落研究 においてコヤの群倉立地について触れたものはいくつか見られる 本報告は他地域に見られない形式をもちながら本格的な調査のな されてこなかった対馬のコヤの建築構法についての詳細な調查を行 ない、その特性について報告するものである。

\section{2. 地域の概要}

対馬は長崎県と朝鮮半島の中間に位置する島である。地形は急 峻で平地は少なく、島の約 9 割を山地が占めている。多くの集落は 河口付近の三角洲地帯に位置し、耕作地が少ないため焼畑農業が近 年までおこなわれていた。海産物資源の豊富な地域であるが、ほと んどの地域において農業が主体であった ${ }^{6}$ 。太古から大陸文化流入 の窓口となっていたが、江戸時代においては、対馬藩の政策により 外部との接触は制限され、集落外への移動さえ自由にはならなかっ $た^{7}$ 。このため昔の民俗文化が色濃く残されている。

\section{3. コヤの分布状況}

コヤは全島に渡って隅々まで分布している。コヤの主要な用途は 穀物の収納倉庫であるため、農業を行なってきた全ての集落におい てコヤを見ることができる。群倉をなしている集落が多く、特徴的 な景観を見せている。多く見られる地域は南西部、北西部、北部で （図-1）その他の地域においてはいくつかのコヤが散在している程 度である。石屋根が残されている地域は、南西部に限られる(図-2)。

本調査は 2004 年 10 月 2 日〜 10 月 15 日および 11 月 18 日〜 12 月 14 日にかけて実施した、主要 30 集落の分布概要調査（次頁表-1）、 12 棟の建築実測図採取、コヤの所有者と大工に対する聞取り調査に 基づくものである。
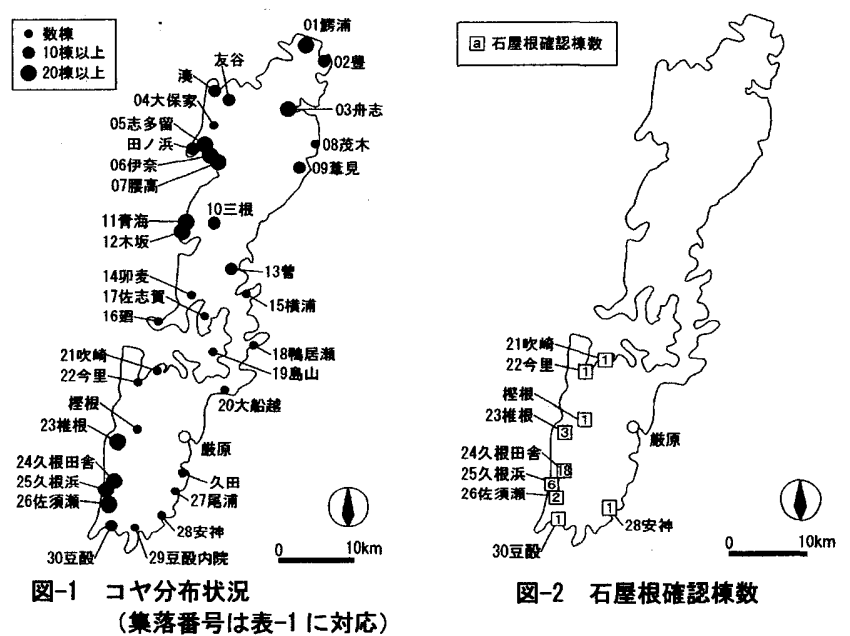

\footnotetext{
*1 Doctoral Program, Graduate School of Comprehensive Human Science, Univ. of Tsukuba

*2 Prof., Grad. Sch. of Comprehensive Human Science, Univ. of Tsukuba, Dr. Eng.

* 3 National Research Institute for Cultural Properties, Nara
}

\footnotetext{
1 筑波大学大学院博士課程人間総合科学研究科 博士課程・デ修

(テ305-8574 茨城県つくば市天王台1-1-1)

$* 2$ 筑波大学大学院人間総合科学研究科 教授. 工博

$* 3$ 奈良文化財研究所
} 
表-1 各集落のコヤ残存状況一筧（集落番号は图-1に対応）

\begin{tabular}{|c|c|c|}
\hline $\begin{array}{l}\text { 集落 } \\
\text { 番号 }\end{array}$ & 雀落名 & コヤ残存状況概要 \\
\hline 01 & 䗆浦 & 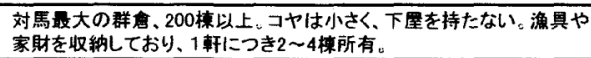 \\
\hline 02 & 豊 & 3楝のコヤを直線状に並べ1枚の屋根で蕉いたものがある。 \\
\hline 03 & 舟志 & $\begin{array}{l}\text { 7群の群倉が形成されている、コヤの残存数は84棟: 前面に下尿を持 } \\
\text { ち、下屡部分に休を張った形式が睍られる。 }\end{array}$ \\
\hline 04 & 茂木 & 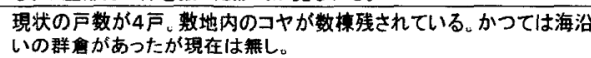 \\
\hline 05 & 䒠見(英胃) & 川沿いに群會。 \\
\hline 06 & 友谷 & 道路を挟んだ対面にコヤが立地。 \\
\hline 07 & 鋘 & 川沿いに群倉。 \\
\hline 08 & 大保家 & 内陸部の宸村集落、広大な耕地を所有、コヤは教地内に立地、 \\
\hline 09 & 志多留 & 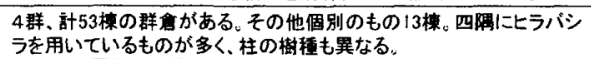 \\
\hline 10 & 田の浜 & 川沿いに群晚。近年まで石屋根が残っていた。 \\
\hline 11 & 伊奈 & 川沿いに20楝ほどの群會。 \\
\hline 12 & 越高 & 3群の群倉 。石屋根が部分的に残っているコヤが1棟あり。 \\
\hline 13 & 三根下里 & $\begin{array}{l}\text { 河川の沉篮に借えた床の高いコヤが多い。宅地内、または隣接して } \\
\text { 立地。 }\end{array}$ \\
\hline 14 & 青梅 & 集落中央の田地治いに18模の群倉： \\
\hline 15 & 木坂 & 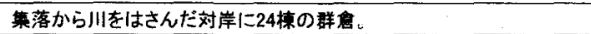 \\
\hline 16 & 曾 & 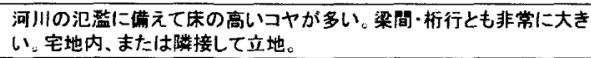 \\
\hline 17 & 構浦 & 入り江の堤防上に群倉。 \\
\hline 18 & 本整居瀨 & $\begin{array}{l}\text { 宅地内の海側にコヤが立地。現在確認できたのは2䜕。網元が地引 } \\
\text { 龬を収納していたアミ゙ヤが线っている。 }\end{array}$ \\
\hline 19 & 悤山 & $\begin{array}{l}\text { 石屋根に用いられたシマヤマイシの産地。現在は石の生産はおこなっ } \\
\text { ておらず、石エの技能も途䋓えようとしている。 }\end{array}$ \\
\hline 20 & 大船越 & コヤは1楝しか残っていない。 \\
\hline 21 & 卯责 & 川沿いに小規模な群冏。他は宅地内にもコヤあり。 \\
\hline 22 & 佐志加 & コヤは宅地内に建てられており、確䍿できたのは4棟。 \\
\hline 23 & 迥 & コヤは宅地内に建てられており、確認てきたのは4棟。 \\
\hline 24 & 久田 & $\begin{array}{l}\text { 石秷根に用いられたクタイシの库地。現在は石の生㦃はおこなってお } \\
\text { らず、石工の技能も途絶えようとしている。 }\end{array}$ \\
\hline 25 & 尾浦 & 海沿いに3梂の群倉。 \\
\hline 26 & 安神 & 海治いに小規模な群會。 \\
\hline 27 & 豆酸内院 & 道沿いに小規模な群會。蓦の立地と重なっている。 \\
\hline 28 & 吹绮 & 川治いに小規模な群會。 \\
\hline 29 & 今里 & 川沿いに7楝の群倉，宅地近くの立地が3菓。 \\
\hline 30 & 撜根 & 宅地内の道沿いにコヤを所有。 \\
\hline 31 & 椎根 & $\begin{array}{l}\text { 川治いに16潇の群會。その他宅地近くのコヤなど22棟。石屋根の石 } \\
\text { 材が特に大きく立派。 }\end{array}$ \\
\hline 32 & 久根田舎 & 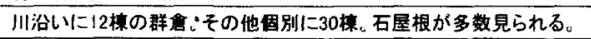 \\
\hline 33 & 久根浜 & $\begin{array}{l}\text { 海沿い、川治い、道治いに3群、計31菓の群會。その他個別に5棟。下 } \\
\text { 屋に床板が張られている。 }\end{array}$ \\
\hline 34 & 佐須頼 & 田地治いに19棟の群葸。 \\
\hline 35 & 豆酸 & $\begin{array}{l}\text { 海治い、川沿いに2 群計14棟の群危。豆配石蓝きを再現した新築のコ } \\
\text { ヤあり。 }\end{array}$ \\
\hline
\end{tabular}

\section{4. コヤの立地と用途}

宅地から離してコヤを集団で建てる群倉立地の見られる集落が多 い。宅地内や宅地に隣接したコヤ配置は平地の多い河川流域か、集 落内に広い敷地を確保しているかっての支配階級の家に多い。

コヤの主な用途は穀物類と家財道具の保存である。前面には農作 業を行ならための広場であるべードコ ${ }^{8}$ が設けられ、またコヤの軒 下、内部でも作業が行なわれており（図-3）、単なる収納空間ではな く、作業空間としての機能も併せ持っている。嬄物の他にも衣類や 什器、貴重品等も収納され、下屋に付室を設け味噌等の加工食品を 保存することも多かった。特殊な用途として台風等の災害時におけ る避難小屋、出産時の産屋、死者が出たときの忌み小屋などにも利 用され、農業生産と梁く結びついた再生装置としての意味づけが読 み取れる。

\section{5. 構法の概要と生産体制 （図-6 参照）}

\section{1. 構法の概要}

コヤの基本形式は高床構造の平屋建てで、壁は板張り、屋根は石 莫きである。高床構造とはいえ床高はそれほど高くはない。基本的

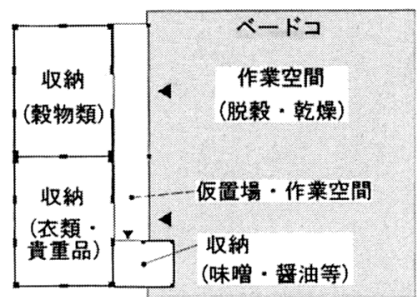

図-3 コヤ利用法 概念図
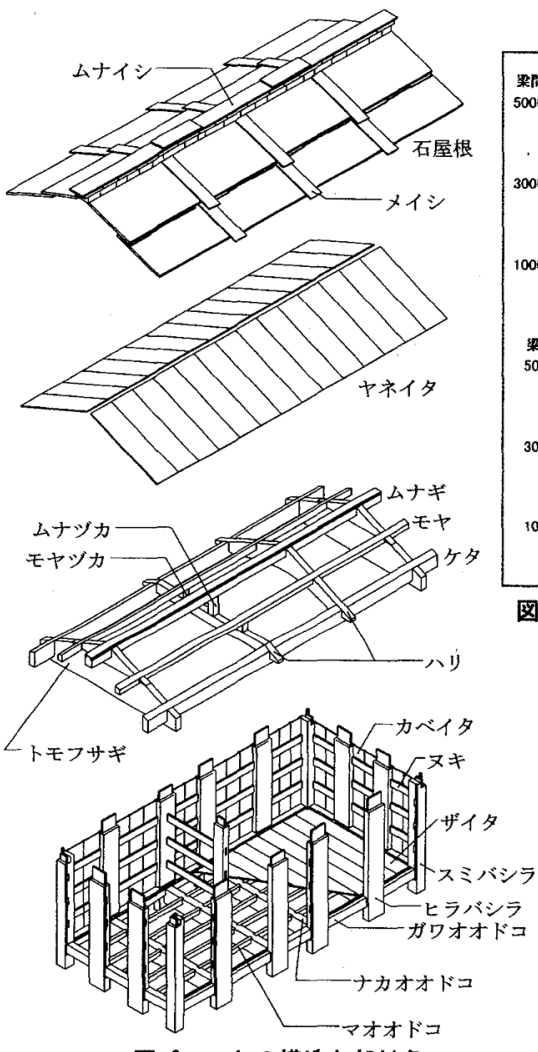

図-6 コヤの權造と部材名

(推根における閉取りによる)

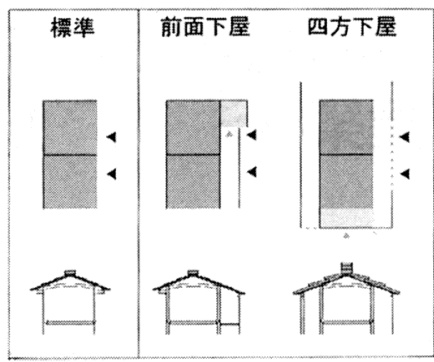

図-4 下屋形式による類型

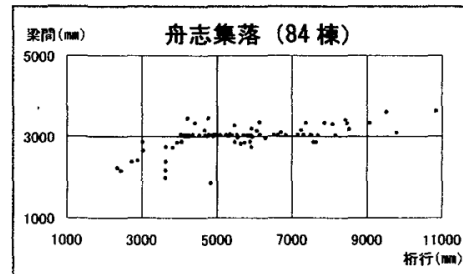

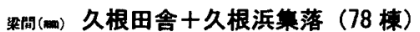

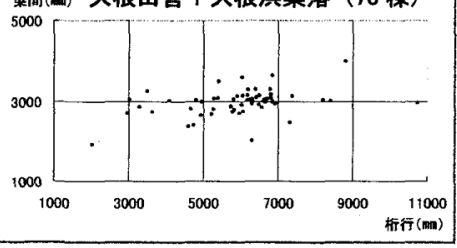

图 -5 梁間・析行寸法の分布（コヤ本体）

\section{表-2 各部材の使用木材種}

\begin{tabular}{|c|c|c|c|c|}
\hline & \multicolumn{2}{|r|}{ 舟志(北部) } & \multicolumn{2}{|r|}{ 檴根(南部) } \\
\hline 平柱·触柱 & \multirow{2}{*}{ 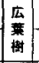 } & 椎、栗、㙌、杉 & \multirow{3}{*}{ 椎 } & 椎 \\
\hline ガワオオド & & 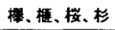 & & 推 \\
\hline 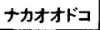 & \multirow{7}{*}{ 杉 } & 杉 & & 椎 \\
\hline マオオドコ & & 杉 & \multirow{5}{*}{ 松 } & 怯、椎 \\
\hline トモフサギ & & 邫 & & 倊 \\
\hline ケターハリ & & 杉、摐 & & 松 \\
\hline ムナキ & & 粀、楼 & & 爷 \\
\hline 玉t & & 杉 & & 松 \\
\hline 又丮 & & 格 & \multirow{3}{*}{ 杉 } & 杉 \\
\hline がイタ & \multirow{2}{*}{ 楛 } & 损 & & 杉、椎 \\
\hline ヤネイタ & & 椎 & & 杉 \\
\hline
\end{tabular}

な建築構法は全島に亘って共通しているが、下屋の形式によって 3 つの類型に分けられる(図-4)。洪水の多い地域では床高さが上げら れ、また特殊な形式として 2 階建てのものも見られる(写真-1 4)。

1 室のものもあるが多くのコヤの内部は $2 \sim 3$ 室に仕切られ、それぞ れの収納物に応じて室ごとに「ヒョウモン(俵物/穀物のこと)ゴヤ」 「イショウゴヤ」「ミンゴヤ」などとよばれている。

建築の規模について、梁間寸法はほとんどのものが 3m 前後で一定 しているが、析行き寸法は $3 \mathrm{~m} \sim 10 \mathrm{~m}$ 程のものまであり（図-5)、桁 行方向の桩大によって建築規模を調整する。

\section{2. 生産体制}

コヤは現在でも利用されており、また近年まで建築されていたた め、大工への聞取りによりその建築過程を知ることができる。 5.2.1. 使用木材種

柱および足固めの材にはシイに代表される広葉樹の硬木、横架材 には松、壁板には杉が用いられる。平柱にはシイの他にクリ・カヤ・ モミ・マツの使用例が確認できた。全般的に鼠害を防ぐために広葉 樹の硬木が好まれる。隅柱のみ硬木を用いるという使い分けもされ る。北部と南部で部材ごとの使用木材種に相違が見られるが(表-2)、 
表-3 実睞を行なったコヤー覧

\begin{tabular}{|c|c|c|c|c|c|c|c|c|c|c|c|}
\hline \multirow{2}{*}{ 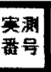 } & \multirow{2}{*}{ 菓落名 } & \multirow{2}{*}{ 建築年代（根猢） } & \multicolumn{2}{|c|}{ コヤ本体 } & \multicolumn{2}{|c|}{ 下屋含む } & \multirow{2}{*}{ 平柱幅 } & \multirow{2}{*}{ 析高さ } & \multirow{2}{*}{ 各部屋の収納物 } & \multirow{2}{*}{ 下屋 } & \multirow{2}{*}{ 注記 } \\
\hline & & & 析行 & 梁間 & 棉行 & 粱間 & & & & & \\
\hline 1 & 舟志 & 明治29 (墨賞) & 9.007 & 3,321 & & & 326 & 2.208 & 犋物・衣類等 & 無L & 一般的なコヤ \\
\hline 2 & 舟志 & 不明 & 9.460 & 3.669 & & 4.829 & 264 & 2.365 & 政物・衣類・什器·味噌 & 前面 & |下屋にミソゴヤを設霜 \\
\hline 3 & 舟志 & 不明 & 10.982 & 3.033 & & 4.078 & 230 & 2.181 & 耗物（大豆・米）・味噌 & 前面 & 2槙を一体化して利用 \\
\hline 4 & 舟志 & 不明 & 3.647 & 3.660 & & & 276 & 3.375 & 不明 & 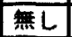 & 2階建 ，棈法も特殊 \\
\hline 5 & 志多留 & 不明 & 8.735 & 3.155 & & & 318 & 1.942 & 不明 & 無し & 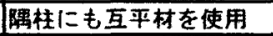 \\
\hline 6 & 三根下里 & 1900年 (伝承) & 6.824 & 3.694 & & & 324 & 2.282 & 効物・衣類等 & \begin{tabular}{|l|} 
無L \\
\end{tabular} & 床㗬が高く、床下を利用 \\
\hline 7 & 仁位 & 江戸時代（伝承） & 7.714 & 3.315 & & & 358 & 2.339 & 㯘物・衣類等 & 無し & 柱間隔が 2 揰類 \\
\hline 8 & 推根 & 昭和32（板図） & 6.248 & 3.145 & 8.278 & 5.077 & 468 & 2.307 & 教物・衣数等 & 四方 & 最も近年の建設 \\
\hline 9 & 椎根 & 19世紀中頃 (推定) & 6.589 & 3.833 & & & 325 & 2.331 & 不明 & \begin{tabular}{|l|} 
無L \\
\end{tabular} & 宮地满神社に移籍 \\
\hline 10 & 久根田舍 & 大正時代（伝承） & 9.757 & 2.960 & 11.293 & 4.434 & 365 & 2.105 & 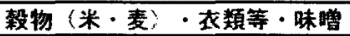 & 四方 & ミソゴヤを妻面に增築 \\
\hline 11 & 久根田舎 & \begin{tabular}{|l|} 
昭和初斯（伝承） \\
\end{tabular} & 5.800 & 2.715 & & 4.215 & 360 & 2.205 & 䟠物・衣類等 & 前後 & 前後に下屋を持つ \\
\hline 12 & 久根田全 & 不明 & 4.975 & 2.570 & & 3.290 & 295 & 2.055 & 不明 & 前面 & 肥後民家村に移築 \\
\hline
\end{tabular}

※析行・染間寸法はコヤ本体部分の外形寸法 平柱幅は析行方向で最大のもの。析高さは平柱接地面より析材下㙐まで。单位は助 ※No.9の建策年代は、野村孝女の推定による

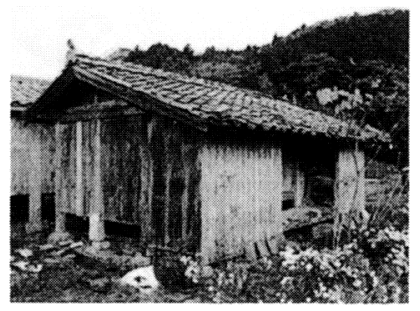

写真-1 前面に下屋のつくコヤ

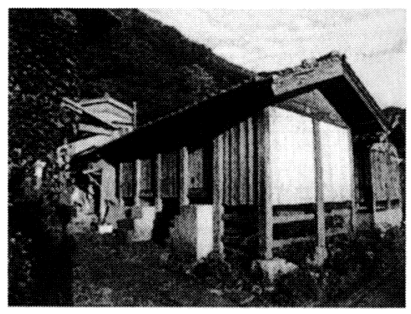

写真-3 床の高いコヤ

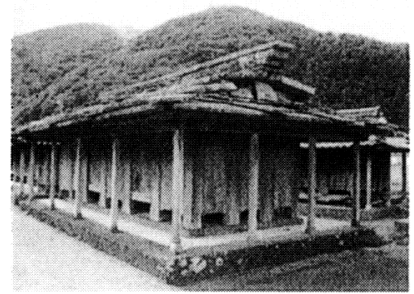

写真-2 四方に下屋のつくコヤ

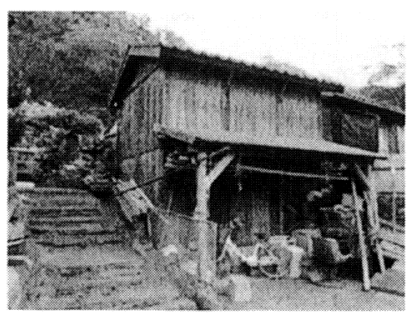

写真-4 2 陵建てのコヤ

これは対馬が南北に長い島であり、南北で樹相が異なるためと思わ れる。

\subsection{2.生産組織}

対馬においては現在でも地域社会に根ざした建築生産方式がとら れることが多く、建築主と大工が一貫してその生産過程に関わって いる。大工は施主の所有する山の木材を選定することから始まり、 製材、加工、建て方、上棟祝いにおける神主役等、全ての作業を統 括している。山師、木婏き等に指示を与えると同時に、自らも作業 を行なった。

\subsection{3. 寸法計画}

コヤの規模は桁行方向の拡大によって調整されるが、それを決定 するのは敷地面積の広さと建て主の希望である。また柱間隔にも基 準となる寸法はない。入口の内々寸法のみが収納物の種類によって 大まかに決められており、その他の柱割りは均等割りにするか壁板 に使用する板材の幅によって決められる。施工上困難が生じると思 われるが、「シャクジョウ (尺杖)」とよばれる析行きと同等の長さ の細材に墨を打ち、物差しとすることで解決している。

\section{6. コヤの実测調查}

本調查においては 12 棟のコヤの実測調查を行なった（表-3）。そ の中から、北部の前面に下屋を持つ形式、南部の四方に下屋を持つ 形式、文化的な先進地域で見られる 2 階建ての形式の 3 例について 報告する。

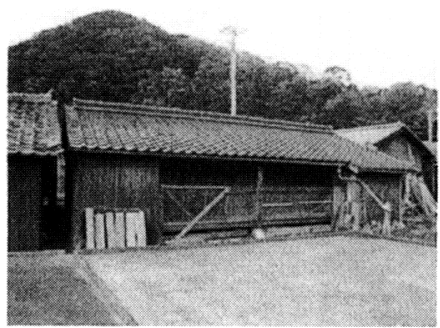

写真-5 舟志のコヤ 外艒

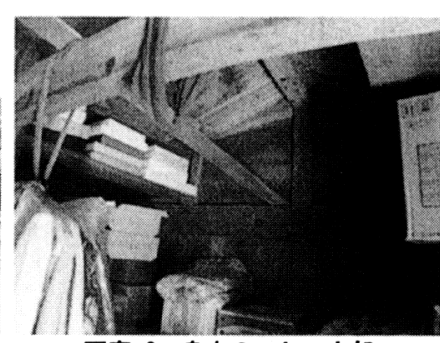

写真-6 舟志のコヤ 内部
6. 1. 舟志 実㨽番号 2 (次頁図 -7 , 写真 -5.6 )

北部に多く見られる、前面にのみ下屋を設け、収納空間・縁側を 付加した形式。

道沿いの群倉内に立地するが、入口が直接道に面していないため 梁間寸法の制限がなく、下屋を造り出し、正面に大きなカンソウバ ${ }^{8}$ (作業場) をもっている。内部は 3 部屋に仕切られ、向かって左が ヒョウモンゴヤ、中央がイショウゴヤ、右がドウグゴヤ。下屋部分 はミソゴヤである。

柱間寸法が統一されており、寸法のぼらつきが大きなコヤ建筑の なかで珍しい。部屋境の梁は折置で組まれ、外部に持ち出された梁 が腕木として利用されている。室内部分の梁は直材を用いて束を立 てている。屋根板のコヤ本体部分は厚板による㹂張りであり、下屋 部分は垂木を設け薄板を横張りしている。

\section{2. 椎根 実測番号 8 (次頁図 -8 , 写真 -7.8 )}

南部に多く見られる、四方に下屋を回し入母屋とした形式。昭和 32 年に建設され、建設年代が確認された中で最も新しい。

川沿いの群倉内に立地している。椎根の大工が自ら施工し所有し ている。柱間寸法のとり方が変則的であるが、これは入口の間口の 寸法には収納物によって一定の基準があるため、まず入口周りの柱 間寸法を決めてから他の柱を配置したためである。梁間寸法は標準 的であるが、平柱が 2 本配置されている。梁・析にはマツ、ガワオ オドコの敷居に当たる部分はクワノキを用い、その他の材は板材を 含めて全てシイである。屋根板は(1)と同様に、下屋部分にのみ垂木 を設けている。トモフサギは厚板を重ねて形成されている。室内部 分の梁は大きな松の曲材によって架けられている。床板の下にも目 板が張られ、壁板は吸付き栈の加工が施されている。

全ての加工において最良と思われる技術が使われており、対馬の コヤの巡り着いた最終形であるといえる。 

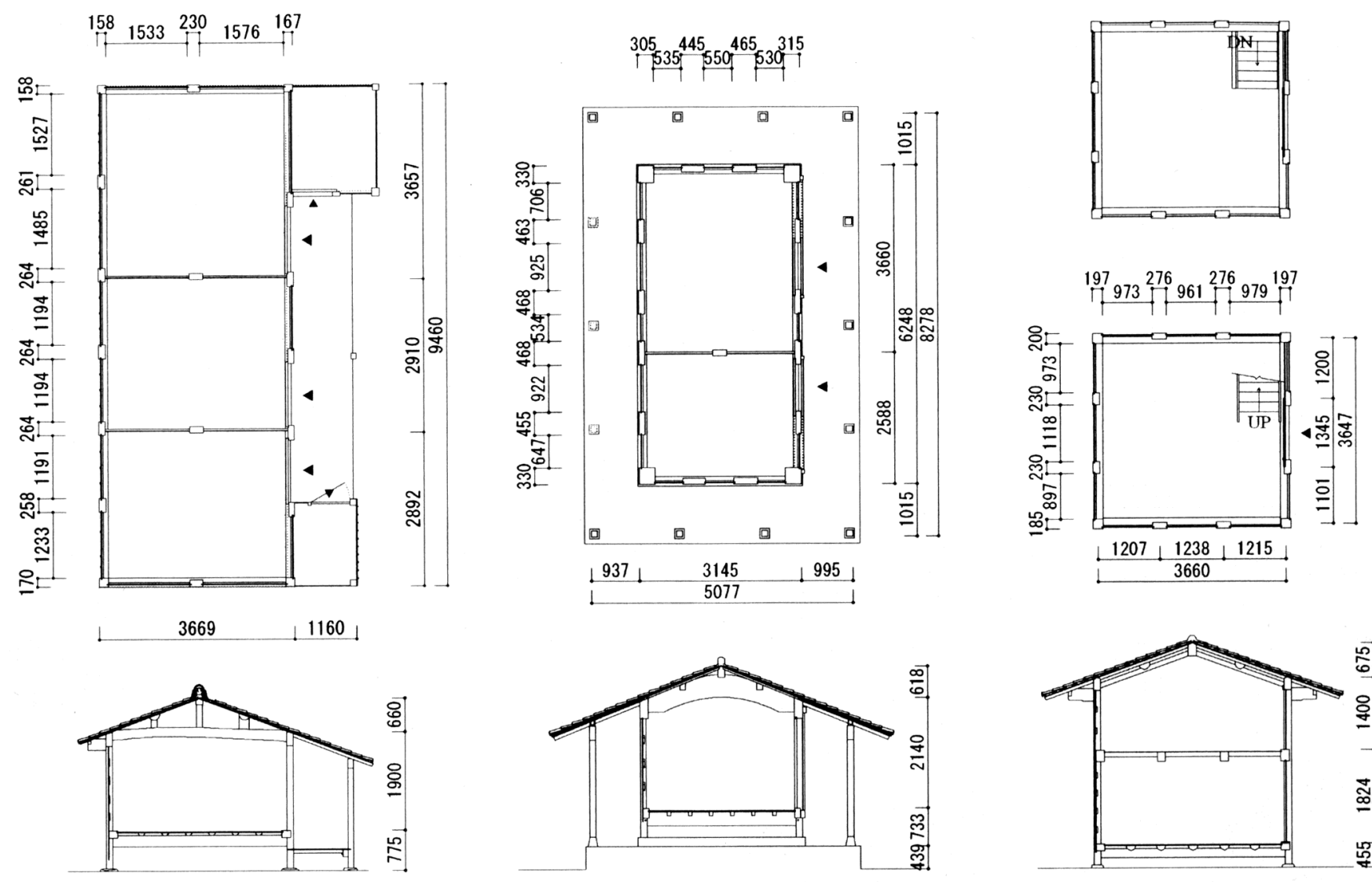

図-7 舟志のコヤ-1 平面図、断面図
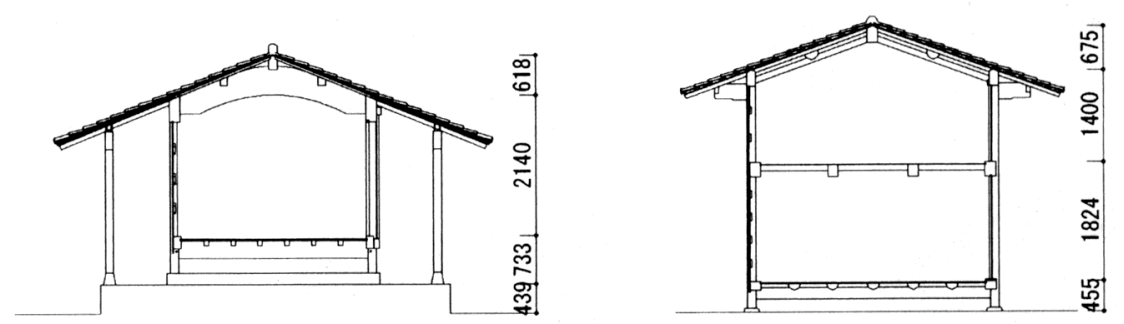

図-8 椎根のコヤ 平面図、断面図

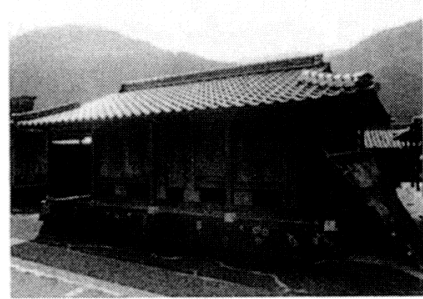

写真-7 椎根のコヤ 外锶

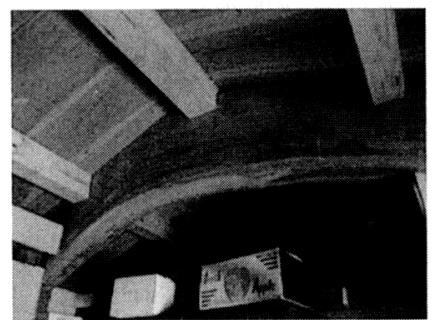

写真-8 椎根のコヤ 内部

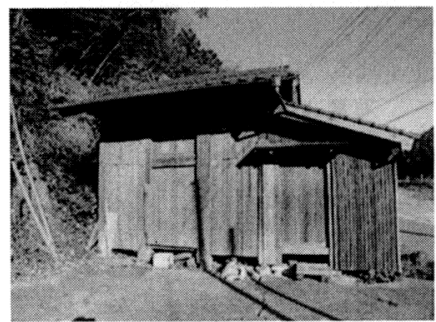

写真-9 舟志のコヤ-2
図-9 舟志のコヤ-2 平面図、断面図

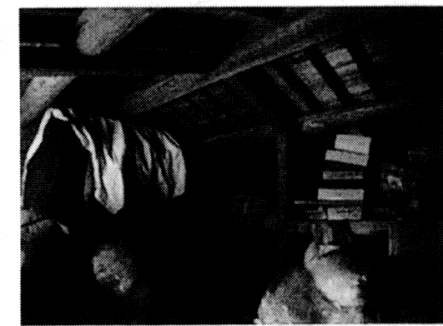

写真-10 舟志のコヤ-2

6. 3. 舟志 実測番号 4 （図 -9 , 写真 -9.10 )

対馬には珍しい2階建ての形式。本調査では6棟が確認されたが、

いずれも鰐浦、舟志、豆酘といった文化的な先進地域であった。

屋敷近くに単独で立地している。2 階にも鍵付きの出入り口が設 けられているが、現状では内部に階段が設けられている。かつては

2 階に直接出入りしたものと思われるが、各階の収納物や利用法は 不明である。2 階建ての形式のものの中には、傾斜地に接して建て られ、 1 ・2 階の入口を反対側に設けることによって、谷側から 1 階に、山側から 2 階に入れるよう工夫したものもある。

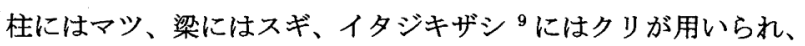
壁板はスギである。屋根は垂木構造となっており、小屋組みには登 り梁が用いられている。登り梁の使用が認められたのはこの 1 棟の

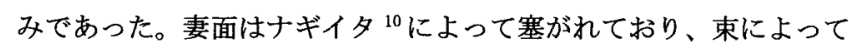
棟木を支えている。ヒラバシラと胴差の仕口は、イタジキザシの仕 口と同様の形式で組まれ、柱はすべて通し柱となっている。ヒラバ シラと 2 階床梁の仕口は特殊な組み方だが、詳細については確認で きなかった。その他の構法については一般的な構造と同様である。

\section{7. 建築搆法の詳細}

7.1. コヤの架構（図-6 参照）

対馬における建築構法の中で最も特徵的なのはヒラバシラの使用 とその仕口（次頁図-10１2）である。ヒラバシラは見付 $180 \sim 420$ m、見込 $120 \mathrm{~mm}$ ほどの長方形断面の柱で、全てのコヤにおいて使用 されている。ヒラバシラの製材においては、丸太を半割りにして形 を整えるという古い手法による製材法がとられていた。ヒラバシラ と足固めの横架材（ガワオオドコ）はカワシオオドコとよばれる仕 口によって組まれている。これはケンドンのように材をかわし、セ ンを打つことによって固定する組み方（図-13）で、構造材の組み方 としては他に類例がない。

スミバシラには正角の材が用いられる。ガワオオドコとスミバシ ラの仕口は 1 枚柄、2枚柄のものが多いが、北部の舟志集落におい ては非常に複雑で特殊な仕口が工夫されている（図-14、15）。

トモフサギとよばれるコヤの妻面の材も特徴的である。妻面にお ける梁材、また妻側の梁と屋根面の間の板材を指す。板材によって 棟木と析を支えており、1 枚の厚い板で作るのが良いとされる。 2 

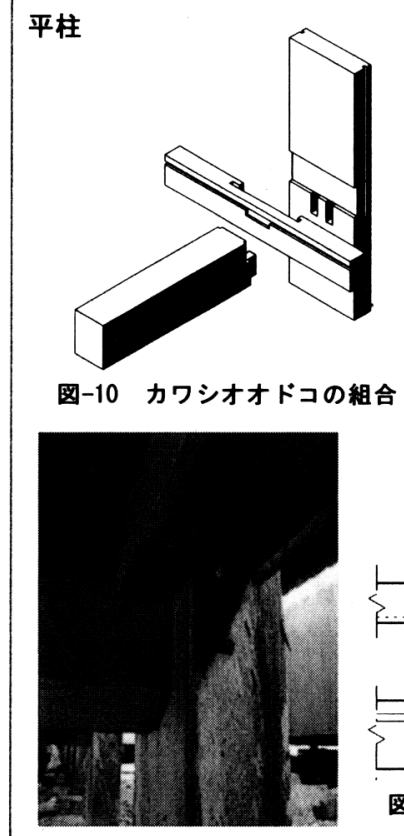

写真-11床下から見た仕口

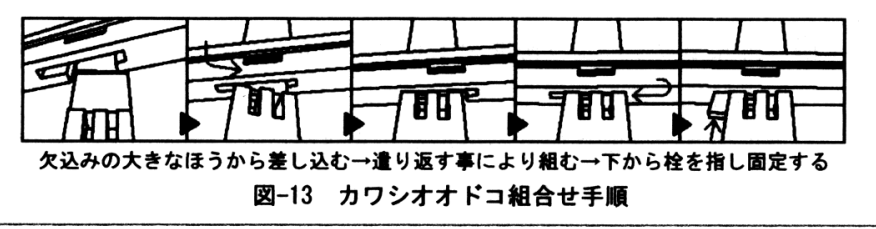

枚以上の板を用いるときは、ダボとメジボウによって隚間を完全に 塞ぐ（図-16）。北部においては棟木を束で支え、薄板で塞いでいる ものが多い。

部屋境の梁材には直材が用いられ、その上に束を建てることによ って楝木と母屋を支えている。部屋中央部分の梁は曲材を使用する ことによって束を省き、室内空間を広くとっているものが多い。

貫はヒラバシラを貫通せず、下げ鎌によって固定されるのが一般 的である（図-17）。ヒラバシラの見付幅が小さなものでは貫がヒラ バシラを貫通しているものも見られる。・

ヤネイタ・カベイタ・ザイタの各板材と構造材の取り合い部分に おいては、板材は構造材に掘られた溝に差し込まれる。ヤネイタは $30 \mathrm{~m}$ 程度の厚板が屋根の両端から設置され、中央の板をカケヤで下 から吒き込むことによって、水が漏れぬよう隙間無く仕上げられる。 近年の建築のものでは、屋根下地にルーフィングが用いられるため、 棟木に满は掘られない（図-18)。カベイタはヒラバシラの間を 1 枚 の板で塞ぐのが理想とされる。1枚板へのこだわりから、吸い付き 㭜によって一体化されたカベイタのパネルをヒラバシラ間にはめ込 むという手法も見られる。カベイタとザイタにおいては、さらに目 板で隙間を塞いだものも見られる。

入口部分のヒラバシラと建具の取合いにおいては、戸当り部分の ヒラバシラをL字型に欠き込み、確実に密閉できるようエ夫されて いる (図-19)。

\section{2. 石屋根の構法}

石屋根は、主要な屋根板部材と、その隙間からの雨水の浸入を防 ぐためのメイシ (目地板部材)、楝押さえのムナイシに分けられる。 南部においては草き石に厚さ $45 \sim 60 \mathrm{~mm}$ 程度、タ夕ミ 1 盢程の石材が
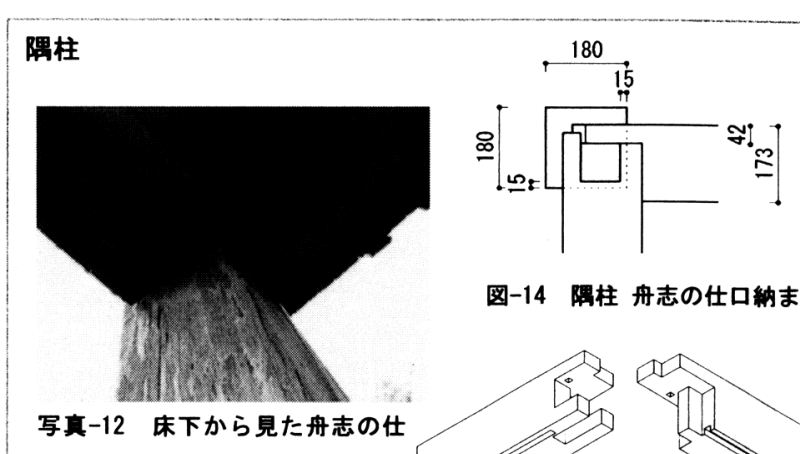

図-14隅柱 舟志の仕口納まり

写真-12 床下から見た舟志の仕

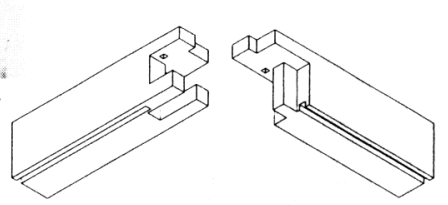

図-15 舟志の壮口 加工詳細

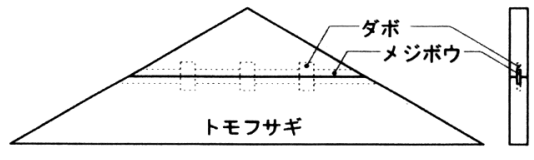

图-16 トモフサギの接合法

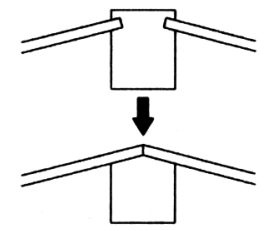

图-18 梾木の加工法

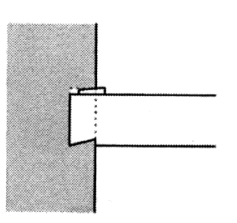
家の固定法
图-17 下げ唋による

用いられることがあるが、これは実用以上に財力の誇示としての要 素が強い。一般的には各集落付近でとれる厚さ 15 mmぼの石を乱積 みにしたものが多かった。莫き方には間隙材を挟むことによって屋 根勾配を一定に保つものと、そのまま莫き重ねていくものがある。 石屋根は維持管理に費用がかかるため: 現在では瓦草に変更されて いるものが多い。石屋根の構法の詳細と施工法については、稿を改 めて報告したい。

\section{8. コヤ各部寸法の比較による地域差の検討}

本調查において舟志集落 (北部) で 84 棟、久根田舎、久根浜集落 (南部)で 78 棟の全てのコヤについての基本寸法の採取を行なった。 その実測結果に基き寸法計画の地域差を検討する。

\section{1. 面積の分布}

梁間・桁行寸法を比較すると（前出図-5）南部において梁間寸法 のばらつきが見られるが、建築面積に関して南北は同様の傾向を示 している(次頁図-20)。しかし1室あたりの床面積は北部において 分布が散っている（図-21）。収納物の種類に応じて床面積を細かく 調節したものであろう。また、北部の舟志においては 1 軒につき 2 棟のコヤを所有し、南部の久根田舎・久根浜においては 1 棟のみ所 有することが多いことも考慮すると、北部地域の農業生産の豊かさ が推測される。

\section{2. ヒラバシラ見付寸法の分布}

ヒラバシラの見付寸法は南部において大きなものが多い(図-22)。 南部においては屋根莫き材に巨大な石材を用いることとの関連が予 測されるが、屋根荷重に直接関わる梁間寸法との対応は認められな い(図-23)。しかし桁高さとの間に比例関係が見られ（図-24）、柱 
の座屈を考慮した寸法計画が確認できる。

\section{3. 下屋の形式}

北部においては下屋無し $: 64$ 棟 $/ 84$ 、前面のみに下屋 : 21 棟 $/ 84$ なのに対して、南部においては四方に下屋 : 65 棟 $/ 78$ であり、地域 差が明らかである。

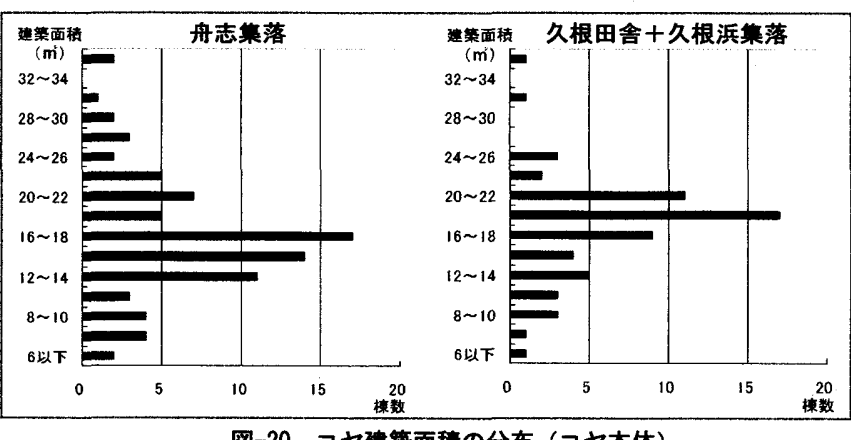

图-20 コヤ建管面稿の分布（コヤ本体）

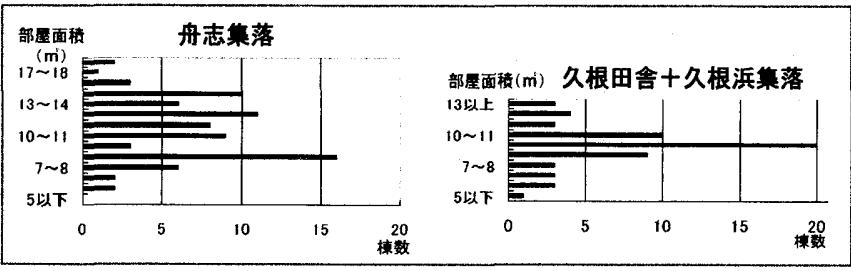

图-21 1 室あたりの床面䖽の分布

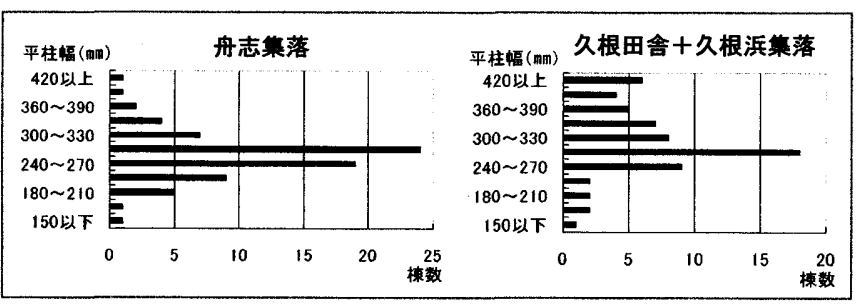

图-22 ヒラバシラ見付寸法の分布

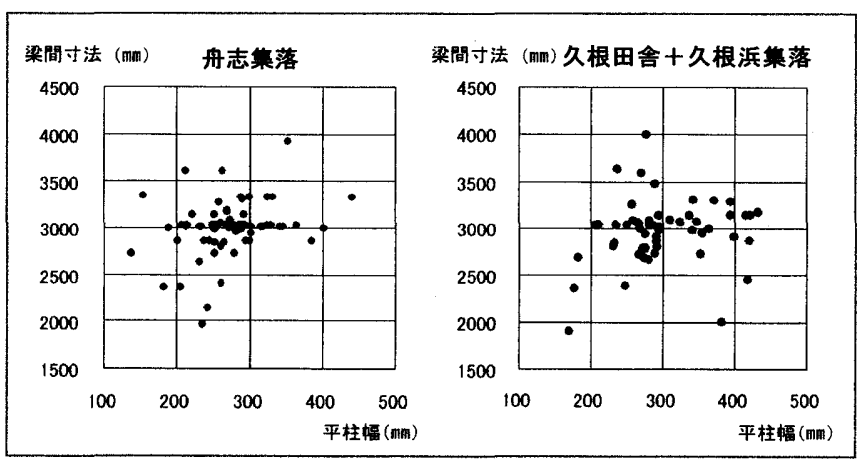

图-23 梁间寸法と平柱見付寸法の関連

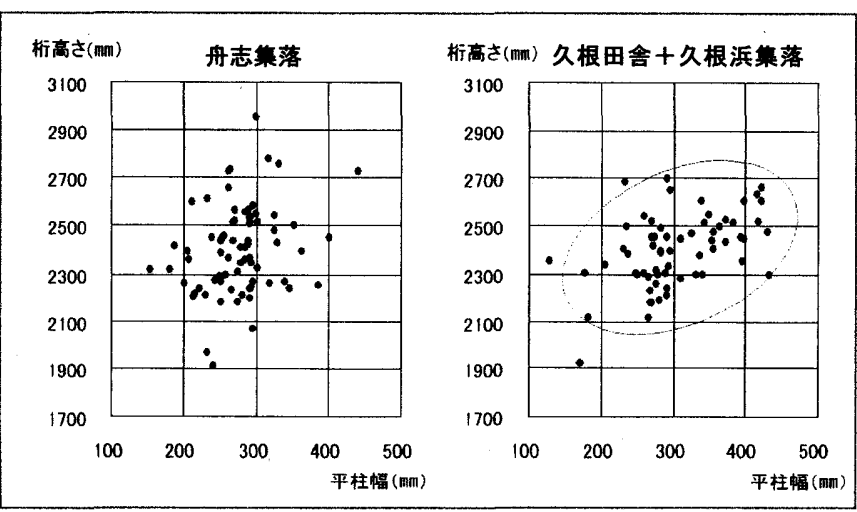

図-24＼cjkstart析高と平柱見付寸法の関連

\section{9. まとめ}

本調査によりコヤの分布状況、形式の類型、構法の詳細、南部と 北部における寸法計画の相違について明らかにすることができた。 しかし、コヤには建築年代の明らかなものが少なく、構法の変遷を 仮定するには至っていない。

対馬のコヤの建築構法には他の地域に見られない手法が用いられ、 特にヒラバシラの使用とその仕口は特徴的である。ヒラバシラの使 用理由については、巨大な石屋根を使用する南部地域において見付 寸法が大きく、また桁高さに比例して大きくなっていることから、 石屋根の荷重に対応した構造部材であることが明らかになった。し かしこれはその理由の一端に過ぎず、その他にも南方からの文化的 な影響や木材加工技術の変遷等の検討を加えることが必要となる。 カワシオオドコの仕ロにおいては、通し貫の用いられない壁体の弱 さを補い、足固めをヒラバシラに緊結し柱の開きを押さえる役割を 果たしている。また、幅の広いヒラバシラを外面に対して美しく見 せるという意匠的な意味ももつ。

構法の特徴としては、その他にもトモフサギの使用やスミバシラ の仕口、板材の施工方法などにも特色が見られ、この地域の特殊性 を示している。これらの部材の加工においては、部材の変形を最小 限に抑えることにより隙間を生じない工夫がなされている。これは 使用木材種の選択と併せて、鼠害を防ぐための工夫である。

対馬のコヤは既往研究が少なく、本研究においてようやく基礎資 料がまとめられた段階である。平柱はコヤのほかにも主屋のダイド コ周りの柱、ウマヤの柱にも用いられている。今後はこれらの建築 物の構法を比較することによって各構法の特徵を捉えコヤの建築構 法を位置づけていきたい。

\section{注・参考文献}

1）「コヤ」は基本的な機能において板倉に分類できるが、特殊な用途として 災害時の避難小屋、出産時の産屋、死者が出たときの忌み小屋などにも利 用され、「クラ」の概念に収まりきらないため、本稿では現地名の「コヤ」 を呼称として用いる。

2）石原憲治，對馬の民家，九學會連合對馬共同調查委員會編，對馬の自然と 文化，古今書院，pp. 318 339，1954.9

3）浅川滋男，離島の建筑 (日本の美術； 406), 至文堂, pp. 26 41，2000.2

4）群倉立地について主要な論文を以下に示す。

伊地知寿子他, 集落内の共有空間-対馬の集落空間構成に関する研究その 2 , 日本建築学会大会学術講演梗概集, 1994

伊地知寿子他，土地所有功見た集落空間-対馬志多留の集落調查報告その 2 ， 日本建築学会中国九州支部報告 第 35 号 3，1995 松永達, 対馬の民家および集落の空間構成と聖性に関する研究, 学位論文, 1997

5）矢野道子，対馬の生活文化史，源流社, pp. 57〜76, 1995.4

6）近世の対馬では海沿いの村であっても漁業を生業とすることは許されず、 公領の土地を分けなおして耕作させ、年貢を納めさせた。参考文献 $4, \mathrm{p} .23$

7）近世においては鎖国が建前であり、また密貿易を防ぐ目的もあり、頻繁に 朝鮮人が訪れる地域でありながら外国人と一般庶民との交流は厳しく制限 され、集落外一の移動も自由にはならなかった。

8）コヤの正面に設けられた縠物を乾燥するなど農作業のための広場。赤土で きれいに固められ、常に清潔に保たれた。地域によって「ベー」「ベードコ」 「ツシロ」などと呼ばれる。

9）舟志における足固め材の呼称。椎根と舟志では部材の呼称が異なるものが ある。舟志においては、ヤネイタ：「ジイタ」、トモフサギ:「ナギイタ」、 ガワオオドコ:「イタジキザシ」、ナカオオドコ:「オオビキ小、マオオドコ： 「コネダ」と呼ばれる。

10) 注 8 参照

[2007年 4 月20日原稿受理 2007年 7 月26日採用決定］ 